\title{
A study on the efficiency of EFQM versus Bass method: Evidence from national land and housing organization
}

\author{
Abolfazl Danaei ${ }^{a}$ and Ensieh Ghafaripour ${ }^{b^{*}}$
}

${ }^{a}$ Department of Management, Semnan Branch, Islamic Azad University, Semnan, Iran

${ }^{b}$ Department of Management, Science and Research branch, Islamic Azad university, Semnan, Iran

\section{CHRON I C L E}

Article history:

Received May 20, 2013

Received in revised format

12 August 2013

Accepted 7 September 2013

Available online

September 112013

Keywords:

Leadership style

Bass model

EFQM model

National land and housing

organization

\section{A B S T R A C T}

Leadership style plays essential role on the success of organizations. The proposed study of this paper compares the efficiency of leadership study based on EFQM and Bass models in national land and housing organization of Iran. The proposed study of this paper designs a questionnaire and distributes it among all managers on this organization. The study covers all different levels of management including middle and top-level management. The results of the survey indicate that the average efficiency of EFQM model is located in $2.7276 \leq X \leq 4.4824$ with $\alpha=5 \%$ while the average efficiency of Bass model is located in $2.674 \leq X \leq 4.326$ with $\alpha=5 \%$. In addition, the survey results indicate that EFQM model provides higher scores than Bass model.

(C) 2013 Growing Science Ltd. All rights reserved.

\section{Introduction}

Leadership style plays important role on management of organizations and many organizations attempt to make necessary changes based on leadership change. There are various studies to measure the effect of different leadership style on the success of organizations. Amani Ashlubolagh et al. (2013) investigated the effect of leadership style among middle level managers of Iran Khodro, the biggest Iranian automaker, to promote innovation among regular workers. The study used t-student test to see the relationship between leadership behavior components and innovation and Freedman test was employed to rank the effects. The results of t-student values demonstrated that all leadership behavior of middle level had positive impact on innovation and Freedman test indicated that stimulating knowledge diffusion was number one priority followed by intellectual stimulation and

*Corresponding author. Tel: +989121316312

E-mail address: ensieh.ghaffaripour@yahoo.com (E. Ghafaripour)

(C) 2013 Growing Science Ltd. All rights reserved. doi: $10.5267 /$ j.ms 1.2013 .09 .012 
innovative role-modeling. They also performed multi-regression analysis and the results indicated that there were some positive relationship between leadership components and innovation.

Abdolmaleki et al. (2013) considered the effects of leadership style on innovation in the same organization. The results of their survey indicated that there was a meaningful difference between leadership style and standard leadership style among middle level managers when the level of significance was five percent. In addition, there was a meaningful difference between innovation and its components with standards among regular employees. Finally, leadership had positive and meaningful effect on employees' innovation. Beikzad et al. (2011) presented an empirical investigation to study on empowering private bank workers using European foundation quality management (EFQM) method. They reported that leadership, academic qualification, appropriate policy and strategy, cooperation and processes played important role on empowering and enabling bank's employee. Kazemi et al. (2011) used EFQM model and reported that organizational excellence pattern of cellulose industry was a mixture of various aspects of technical, economic, inner environment, outer environment, motivation and behavioral processes.

Abbasi and Farhangi (2011) permed an empirical study of implementation of EFQM method for broadcasting organization in Iran. They discussed that performance measurement plays an essential role on media organizations and there are literally many methods for measuring the performance of an organization including EFQM, which is one of the most popular methods for measuring performance of organizations. They performed an empirical survey to customize this method for broadcasting organization of Iran. They analyzed and assigned some points to various criteria and realized that standard EFQM could be considered as a customized method for taking appropriate strategies in this organization.

\section{The proposed method}

The proposed study of this paper compares the efficiency of leadership study based on EFQM model and Bass models in national land and housing organization of Iran. The proposed study of this paper designs a questionnaire and distributes it among all managers on this organization. In this survey, we first apply Bass leadership style in this organization during the years of 2010 and 2011 and then we use EFQM method for 2011 and 2012 and finally compare these two leaderships. The study covers all different levels of management including middle and top-level management. We first present details of personal characteristics of the participants. In our survey, $59 \%$ of the participants were male and the remaining people were female. Fig. 1 demonstrates participants' educational background and age.

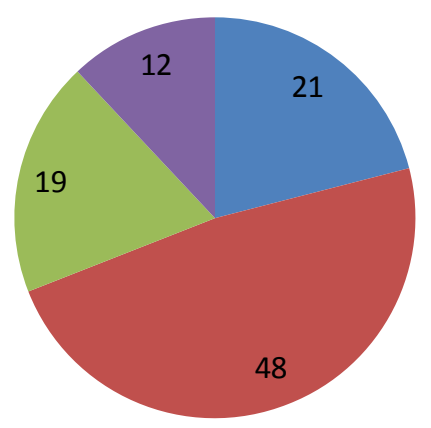

$\square 18--30 \quad$ 31-40 $\quad 41-50 \quad \square>50$

Frequency of age

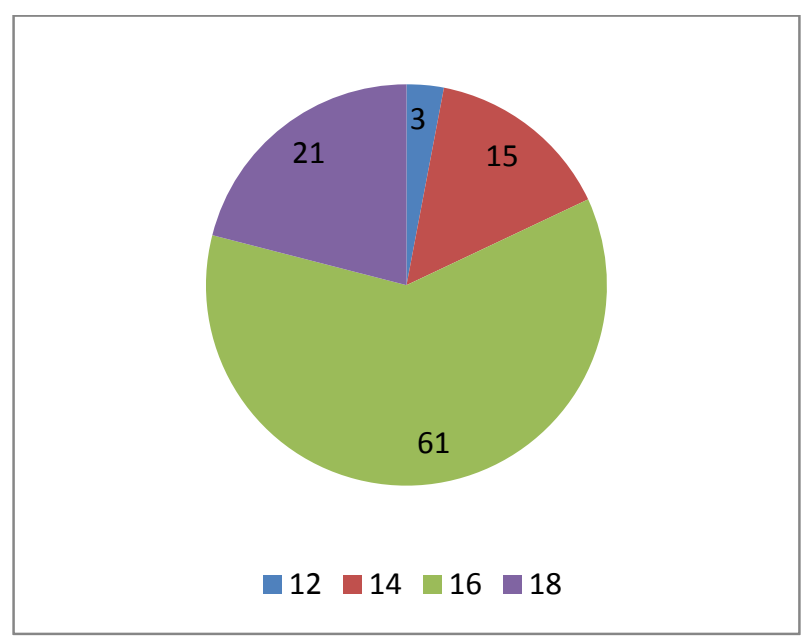

Years of educational background

Fig. 1. Personal characteristics of the participants 
The results of Fig. 1 demonstrate that most participants were middle age and hold good educational backgrounds. The proposed study of this survey applies two leadership styles based on EFQM and Bass models in two different periods. Table 1 summarizes some basic statistics on EFQM.

\section{Table 1}

The summary of some basic statistics for EFQM leadership style model during the years of 2011-2012

\begin{tabular}{|c|c|c|c|c|}
\hline EFQM leadership style & & Top-level managers & Middle level managers & Executive managers \\
\hline Mean & & 3.6 & 2.876 & 2.7004 \\
\hline \multirow{2}{*}{$\begin{array}{l}95 \% \text { confidence } \\
\text { interval }\end{array}$} & Lower bound & 2.7176 & 2.1997 & 2.371 \\
\hline & Upper bound & 4.4824 & 3.5523 & 3.0299 \\
\hline Median & & 3.96 & 2.92 & 2.92 \\
\hline Variance & & 1.521 & 2.088 & 1.909 \\
\hline Standard deviation & & 1.23349 & 1.44494 & 1.38165 \\
\hline Min & & 1.25 & 1 & 1 \\
\hline Max & & 5 & 5 & 5 \\
\hline Range & & 3.75 & 4 & 4 \\
\hline
\end{tabular}

As we can observe from the results of Table 1, EFQM model seems to be more successful model compared with other two models and top-level management maintains the highest score with minimum standard deviation followed by middle level and executive managers. Table 2 demonstrates the summary of our survey on Bass leadership style (Bass, 1985, 1990; Bass \& Bass, 2008).

Table 2

The summary of some basic statistics for Bass leadership style during the years of 2010-2011

\begin{tabular}{|c|c|c|c|c|}
\hline Bass leadership style & & Top-level managers & Middle level managers & Executive managers \\
\hline Mean & & 3.5 & 2.8 & 2.6214 \\
\hline \multirow{2}{*}{$\begin{array}{l}95 \% \text { confidence } \\
\text { interval }\end{array}$} & Lower bound & 2.674 & 2.154 & 2.3093 \\
\hline & Upper bound & 4.326 & 3.446 & 2.9335 \\
\hline Median & & 3.75 & 2.50 & 2.50 \\
\hline Variance & & 1.333 & 1.905 & 1.713 \\
\hline Standard deviation & & 1.1547 & 1.38031 & 1.30893 \\
\hline Min & & 1.5 & 1 & 1 \\
\hline $\operatorname{Max}$ & & 5 & 5 & 5 \\
\hline Range & & 3.5 & 4 & 4 \\
\hline
\end{tabular}

The results of Table 2 are similar to what we see earlier on the effect of EFQM model. In other words, Bass model seems to be more successful model compared with other two models and top-level management maintains the highest score with minimum standard deviation followed by middle level and executive managers. The results of the survey indicate that the average efficiency of EFQM model is located in $2.7276 \leq \bar{X} \leq 4.4824$ with $\alpha=5 \%$ while the average efficiency of Bass model is located in $2.674 \leq \bar{X} \leq 4.326$ with $\alpha=5 \%$. In addition, the survey results indicate that EFQM model provides higher scores than Bass model. Table 3 demonstrates the results of scores for two leadership styles.

Table 3

The summary of comparing basic statistics on two leadership styles

\begin{tabular}{|c|c|c|c|c|c|c|c|c|c|}
\hline & & \multicolumn{3}{|c|}{$2010-2011$} & \multicolumn{5}{|c|}{ 2011-2012 } \\
\hline & & $\begin{array}{c}\text { Top } \\
\text { manageme }\end{array}$ & $\begin{array}{l}\text { Middle level } \\
\text { management }\end{array}$ & $\begin{array}{c}\text { Executive } \\
\text { management }\end{array}$ & Mean & $\begin{array}{c}\text { Top } \\
\text { management }\end{array}$ & $\begin{array}{l}\text { Middle level } \\
\text { management }\end{array}$ & $\begin{array}{c}\text { Executive } \\
\text { management }\end{array}$ & Mean \\
\hline Mean & & 3.9 & 3.175 & 2.94 & 3.34 & 4.001 & 3.33 & 3.1113 & 3.48 \\
\hline $95 \%$ & Lower & 3.007 & 2.46 & 2.58 & 2.683 & 3.19 & 2.6754 & 2.7753 & 2.8802 \\
\hline interval & Upper & 4.793 & 3.88 & 3.3 & 3.995 & 4.81 & 3.9846 & 3.4473 & 4.081 \\
\hline Median & & 4.375 & 3.75 & 3.75 & 3.958 & 4.435 & 3.86 & 3.86 & 4.052 \\
\hline Variance & & 1.558 & 2.31 & 2.316 & 2.061 & 1.286 & 1.956 & 1.985 & 1.742 \\
\hline Standard deviation & & 1.248 & 1.519 & 1.521 & 1.43 & 1.133 & 1.39873 & 1.40907 & 1.314 \\
\hline Min & & 1.5 & 1 & 1 & 1.167 & 1.82 & 1.14 & 1.14 & 1.367 \\
\hline Max & & 5 & 5 & 5 & 5 & 5 & 5 & 5 & 5 \\
\hline Range & & 3.5 & 4 & 4 & 3.833 & 3.18 & 3.86 & 3.86 & 3.633 \\
\hline
\end{tabular}


The results of Table 3 show that the mean scores of leadership styles during the years of 2011-2012 were better than 2010-2011. We now try to find out whether EFQM performed better than Bass model or not in this organization. In order to test the main hypothesis of this survey, the null and alternative hypotheses are as follows,

$$
\left\{\begin{array}{l}
H_{0}: \mu_{d}=0 \\
H_{1}: \mu_{d} \neq 0
\end{array}\right.
$$

Table 4 shows the summary of our findings on testing the main hypothesis of this survey.

\section{Table 4}

The summary of testing the main hypothesis of this survey on difference between Bass and EFQM

\begin{tabular}{ccccccc}
\hline \multirow{2}{*}{ Mean difference } & $\begin{array}{c}\text { Standard deviation of } \\
\text { differences }\end{array}$ & \multicolumn{2}{c}{$95 \%$ confidence interval } & \multirow{2}{*}{ t-student } & df & Sig. \\
\cline { 3 - 6 } & 0.03072 & Lower & Upper & & & \\
\hline-0.0708 & & -0.13176 & -0.00984 & -2.305 & 99 & 0.023 \\
\hline
\end{tabular}

Based on the results of Table 4, we can conclude that EFQM performs better than Bass method.

\section{Conclusion}

In this paper, we have presented an empirical survey to compare the performance of EFQM versus Bass method in one of Iranian organization. The study performed both leadership styles in two consecutive years and compared them using t-student test. The results of our survey have concluded that EFQM performed better than Bass method in this firm.

\section{Acknowledgment}

The authors would like to thank the management team of national land and housing organization in Iran for cordially cooperating in accomplishment of this survey.

\section{References}

Abbasi, M., \& Farhangi, A.A. (2011). An empirical study of implementation of EFQM method for broadcasting organization in Iran. Management Science Letters, 3(3), 961-966.

Abdolmaleki, J., Amani Ashloublagh, M., Ameri Shahrabi, M., Kazemi Ashlaghi, A., Safdari, S. (2013). A study on effects of leadership style on innovation: A case study from automaker industry. Management Science Letters, 3(7), 1977-1982.

Amani Ashlubolagh, M., Ameri Shahrabi, M., Eftekhari, J., Kazemi Ashlaghi, A., Safdari, S., \& Abdolmaleki, S. (2013). A study on the effect of manager's leadership style to create innovation among employees. Management Science Letters, 3(8), 2201-2206.

Bass, B. M. (1985). Leadership and performance beyond expectations. New York, NY: Free Press.

Bass, B. M. (1990). Bass \& Stogdill's handbook of leadership: Theory, research, and managerial applications, $3^{\text {rd }}$ ed., New York, NY, US: Free Press.

Bass, B. M. \& Bass, R. (2008). The Bass handbook of leadership: Theory, research, and managerial applications, $4^{\text {th }}$ ed., New York: Free Press.

Beikzad, J., Majnooni Totakhaneh, Y., \& Ghorbannejad Maleki, S. (2011). An empirical study on empowering private bank workers using EFQM. Management Science Letters, 2(1), 321-328.

Kazemi, S.A., Salehi Sadaghani, J., Nikokar, G.H., \& Mohammad Sadeghi, M. (2011). Designing organizational excellence model for cellulose industry of Iran. Management Science Letters, 2(1), 107-112. 